\title{
Osiński poznański
}

Niniejszy tekst jest zapisem seminaryjnego spotkania poświęconego pamięci profesora Zbigniewa Osińskiego, teatrologa, pomysłodawcy i pierwszego dyrektora Ośrodka Badań Twórczości Jerzego Grotowskiego i Poszukiwań Teatralno-Kulturowych (dziś: Instytutu im. Jerzego Grotowskiego) we Wrocławiu, badacza twórczości Juliusza Osterwy, Jerzego Grotowskiego, teatru Gardzienice, Tadeusza i Ireny Byrskich, recepcji teatru orientalnego w Polsce. Spotkanie, które zorganizował Instytut Teatru i Sztuki Mediów WfPiK UAM w Poznaniu, odbyło się 5 października 2018 roku w Sali Teatralnej im. Wojciecha Bogusławskiego w Collegium Maius. Składało się z dwóch odsłon: części referatowej (były to trzy zwięzłe wystąpienia: profesor Dobrochny Ratajczakowej o początkach kariery naukowej Zbigniewa Osińskiego, profesor Elżbiety Kalemby-Kasprzak - o poznańskim „praktykowaniu humanistyki”, i profesora Ryszarda K. Przybylskiego - o słynnym artykule Edwarda Balcerzana i Zbigniewa Osińskiego wykorzystującym narzędzia teorii informacji) oraz części wspomnieniowej, podczas której zaproszeni goście przywoływali wydarzenia z lat 60 . xx wieku i dzielili się refleksjami o poznańskim okresie działal- 
ności artystycznej i naukowej Profesora Osińskiego. Wśród gości seminarium znaleźli się m.in.: Edward Balcerzan, Lech Raczak, Piotr Frydryszek, Janina Karasińska - a więc przyjaciele i współpracownicy Profesora Osińskiego - a także pracownicy i studenci Wydziału. Gościem honorowym spotkania była profesor Katarzyna Osińska. Naszym seminarium chcieliśmy nie tylko uhonorować Profesora - w (niemal) pierwszą rocznicę Jego śmierci - ale też przypomnieć, że Jego droga naukowa zaczęła się kształtować właśnie tu, w Poznaniu, gdzie pracował do roku 1970.

Profesor Osiński był niezwykle ważnym punktem odniesienia dla wielu z nas - zajmujących się sztuką teatru, jego społecznym usytuowaniem, budowanymi przezeń relacjami międzyludzkimi. Chcieliśmy przywołać i spróbować uchwycić cechy utrwalone we wczesnych pracach naukowych i artystycznych, opowiedzieć Jego poznański „start”, przywołać Go raz jeszcze w tych przestrzeniach, które kiedyś zamieszkiwał, a potem często odwiedzał.

\section{Dobrochna Ratajczakowa, O Zbyszka Osińskiego latach naukowego terminowania}

Przywykłam do łączenia prac naukowych Zbyszka na wczesnym, poznańskim etapie Jego działań, z profesorem Jerzym Ziomkiem. Było tak już wtedy, gdy Jerzy uruchomił poświęcone teatrowi seminarium magisterskie, na które się zapisałam. Seminarium to, pozbawione wsparcia szerszego, całościowego programu zajęć, niejako „przemycało” teatr między polonistycznymi wykładami i ćwiczeniami. Wspierał je przez chwilę zaproszony przez Jerzego niezwykły człowiek teatru, Stanisław Hebanowski, kierownik literacki poznańskich scen dramatycznych, który zaznajamiał nas z tzw. Wielką Reformą Teatru i jej francuskim odpowiednikiem tzw. Kartelem Czterech. Zbyszek zaś jako młody asystent pojawiał się na seminarium razem $z$ profesorem, czasem też $w$ towarzystwie Edwarda Balcerzana; bywało, że prowadził zajęcia w zastępstwie Jerzego. Kiedy po skończonych studiach dołączyłam do zespołu Zakładu Teorii Literatury, kierowanego przez Jerzego, podzieliliśmy nie tylko zauroczenie rozwijającą się wtedy w szybkim tempie teorią, ale też... pokój w Collegium Philosophicum (także 
z Balcerzanem). Była to 2. połowa lat 6o., początek złotego czasu teorii literatury.

Tymczasem po latach stwierdziłam, że to nie Jerzy był pierwszym mistrzem Zbyszka, lecz profesor Zygmunt Szweykowski. Rację miał Andrzej Wysiński, który wymienił jego nazwisko w gronie prekursorów i "przemytników” teatrologii z lat 40. i 50., a jako jeden z „przyczółków” nauki o teatrze wskazał Uniwersytet Poznański. Zanim Profesor po prawie dwudziestu latach nauczania na poznańskiej polonistyce (od 1945 roku) został w roku 1964 emerytowanym profesorem, wykładał przedmioty o bardzo zróżnicowanej tematyce. Były wśród nich zarówno zajęcia z poetyki, jak i z powieści Henryka Sienkiewicza i Bolesława Prusa czy twórczości Stefana Żeromskiego; był polski dramat xIX-wieczny, komedia pozytywistyczna i romantyczny poemat historyczny. Rozrzut tematów jest spory, ale przecież nie same tematy liczą się w uniwersyteckiej dydaktyce. Czego zatem de facto uczył profesor Szweykowski? Na pewno traktował dydaktykę jak misję - o czym wspominają jego uczniowie. Na pewno uczył czytać i analizować dzieło literackie umieszczane przez niego w ramach badań filologiczno-historycznych. Poza tym uczył także dostrzegać i badać związki między tym dziełem a biografią autora - czego także dowodzą jego prace. W tle znajdziemy tu neoidealizm niemiecki i poglądy Wilhelma Diltheya. W dziele bowiem najlepiej ujawniają się relacje między indywidualną strukturą psychiczną a strukturą duchową epoki - co Profesor pokazał w przedwojennej pracy poświęconej Lalce Prusa, a po latach - w monografii tego pisarza.

Na zajęciach jednak nie tylko zajmował się literaturą, ale także uczył analitycznego podejścia do dramatów - co zademonstrował później w świetnym drobiazgu, wykazującym związki Pana Damazego (uważanego za arcypolską komedię) Józefa Blizińskiego z Notariuszem Guerin francuskiego autora Emila Augiera. Z kolei na wykładach - jak zanotował Zbigniew Raszewski w Trudnym rebusie - przekazywał swym uczniom także wiedzę inną, praktyczną, np. o tym, że nauka zaczyna się od podziałów. „To najważniejsza rzecz w nauce” - komentował Raszewski. Zatem prowadząc wykłady z dramatu i komedii, Szweykowski uczył swych słuchaczy, że dla literatury i teatru konieczne są odrębne kryteria 
badawcze. Wszak tekst w teatrze traci swą literacką autonomię (jeśli ją w ogóle ma), w związku z czym badania spektaklu teatralnego muszą objąć sferę odbioru. To widz bowiem decyduje o losie sztuki, podczas gdy sam określony jest przez warunki, w których żyje. Teatr jest przecież instytucjonalnym wytworem zbiorowości, a doceniając różnorodność jego form, także form niskich i popularnych (których funkcji zawsze bronił), napisał Szweykowski pionierską wtedy historię warszawskich scen ogródkowych.

Wiedzę o tym, czego uczył profesor, czerpię ze szczególnych dokumentów. Tak się bowiem złożyło, że w moim posiadaniu są zapisy wykładów Szweykowskiego z dramatu i komedii 2. połowy XIX wieku. Notatki te wyszły spod piór jego zdolnych studentów: Raszewskiego, jego późniejszej żony Anny Micewiczówny, Edwarda Pieścikowskiego i jeszcze jednej, niezidentyfikowanej osoby. Cały zbiór podarował mi właśnie Pieścikowski, który go troskliwie przechowal przez lata. Dzięki temu mogę teraz przybliżyć postać pierwszego mistrza Zbyszka. To bowiem profesor Szweykowski ukształtował podstawy Jego naukowych działań i obdarzył Go energią badawczą, nawet jeśli Jego drugi nauczyciel, profesor Ziomek, nadał im potem inny kierunek.

Nie jest bez znaczenia, że Osiński znalazł się w gronie świetnych uczniów Szweykowskiego, również przyszłych profesorów, obok wspomnianego już Zbigniewa Raszewskiego, Jarosława Maciejewskiego, Michała Witkowskiego, Edwarda Pieścikowskiego, Lecha Słowińskiego czy Edmunda Jankowskiego. W świetle poglądów Szweykowskiego znamienny pozostaje temat pracy magisterskiej Zbyszka poświęconej recepcji Marchołta Jana Kasprowicza w polskim teatrze, a także temat rozprawy doktorskiej o scenicznych wcieleniach Wyzwolenia Stanisława Wyspiańskiego. W obu przypadkach były to prace skoncentrowane na wybitnym i oryginalnym dziele literackim, ale dotyczące teatru, nie literatury. Kontekst wykładów (i poglądów) profesora Szweykowskiego jest tu nader istotny. Obie rozprawy stanowily punkt wyjścia dla późniejszych sposobów widzenia i traktowania teatru przez Zbyszka. Zbiegają się w nich dwie linie - historyczna i analityczna, w zgodzie z naukami Jego pierwszego mistrza. 
Edukacji Zbyszka dopełnił bowiem, jak wspomniałam, mistrz drugi, profesor Ziomek. Tym razem była to edukacja teoretyczna poczynając od fenomenologii i jej ówczesnej „alfy i omegi”, czyli Romana Ingardena, przez strukturalizm i semiotykę. Zakład Teorii Literatury budował wtedy otwartą bazę teoretyczną, która nie wykluczała wycieczek na inne obszary - nie tylko nauki (jak w stronę interesującej Jerzego teorii informacji), ale i żywego teatru. Wtedy właśnie powstał artykuł Balcerzana i Osińskiego oświetlający spektakl teorią informacji. Był to także moment początku współpracy Zbyszka ze szczególnym podówczas pismem teatralnym, czyli z „Proscenium”. Pismo zostało założone w sezonie 1963/1964 przez Ziomka i Stanisława Hebanowskiego, a współredagowali je właśnie Osiński i Milan Kwiatkowski. „Proscenium” reaktywowało tradycję tego rodzaju działań „przyteatralnych” z dwudziestolecia międzywojennego. Pisma takie wychodziły wtedy nie tylko w Warszawie czy Krakowie, ale i w Poznaniu - tu w 1929 roku zaczął się ukazywać „Świat Kulis”, a w 1948 roku „Echo Teatralne i Muzyczne”. W „Proscenium” można było szlifować pióro i publikować $\mathrm{w}$ formie niewielkich artykułów wyniki swoich badań (co również czyniłam); tu właśnie Zbyszek zamieszczał swe teksty popularyzujące dokonania tzw. Wielkiej Reformy Teatru. W pierwszym numerze wydrukowano jego Legendę o Leonie Schillerze, w drugim Lekcję biomechaniki u Wsiewołoda Meyerholda, w kolejnych - artykuły O plastyce teatralnej Andrzeja Pronaszki $z$ przekora czy o inscenizacjach dramatów Ferdynanda Crommelyncka. Obok nich znalazł się także „odprysk” z jego pracy magisterskiej - tekst O lwowskiej inscenizacji Marchołta w reżyserii Wacława Radulskiego. Na ten sam 1965 rok przypada też opublikowany w innym miejscu artykuł o tytule jak ze Szweykowskiego: O stosunku widowiska teatralnego do dramatu.

Specjalnością poznańskiego ośrodka badawczego stał się - jak uważa Milan Lesiak, autor Dziejów polskiej nauki o teatrze w latach 1945-1975 - cechujący Zakład Teorii Literatury wyrazisty krytycyzm. Ujawniał się on zarówno w regularnych spotkaniach naukowych Zakładu, jak i w naszych tekstach. W przypadku Zbyszka można go zauważyć w artykule Teatrologia nauka podejrzana z 1968 
roku, atakującym „Pamiętnik Teatralny”. Tekst ten wzbudził wówczas spore zamieszanie w świecie teatrologów.

Wydaje się więc, że w sumie Zbyszek miał dwu mistrzów o całkowicie odmiennych poglądach i warsztatach badawczych: wykształconego w dawnej szkole polonistyki znawcę pozytywizmu: profesora Szweykowskiego, i nowoczesnego teoretyka, badacza oświecenia: profesora Ziomka. Każdy nauczył Go czegoś innego, obaj jednak „wplątali” Go w teatr. I uczynili to nader skutecznie.

\section{Elżbieta Kalemba-Kasprzak, Poznań i praktykowanie}

\section{humanistyki}

Istnieje historia historyków i historia doświadczana przez ludzi bezpośrednio. Życie i historia nie stanowią jednak opozycji, to raczej aspekty tego, co się dzieje i wydarza. Zbigniewa Osińskiego interesował taki rodzaj teatru, który wynikał z ludzkiego doświadczenia i stanowił jednocześnie jego medium. Choć „praktykowaniem humanistyki” nazwał wczesny etap działalności teatru Gardzienice, to ta formuła znakomicie oddaje także jego własną działalność: charakterystyczną postawę poznawczą wyrażającą się w relacjach z ludźmi, w byciu uczestnikiem/świadkiem wydarzeń, w silnym uwrażliwieniu na obecność tradycji, w podejmowanych zadaniach opisania tych międzyludzkich relacji.

Zbyszek był poznaniakiem z urodzenia i mieszkał tu przez pierwszych trzydzieści lat życia i edukacji. Realizował tę poznańskość w sposób szczególny (a może to poznańskość tak szczególnie realizowała się w nim), charakteryzujący się filologicznym porządkiem. Jedną jego stroną była niezwykła dokładność i skrupulatność, objawiająca się np. robieniem notatek ze znaczących i ważnych dla niego spotkań (z takich notatek powstała później książka Spotkania z Jerzym Grotowskim, w której widać dobrze tę filologiczną szkołę niesłychanej pieczołowitości, dbałości o szczegóły). Towarzyszyła temu fascynacja strukturalizmem, semiotyką, która ewoluowała z czasem w stronę antropologii kulturowej. Intelektualnymi patronami tej postawy byli dwaj poznańscy profesorowie: Zygmunt Szweykowski i Jerzy Ziomek. Trzecim, 
najważniejszym bodaj mistrzem (spotkanym już w teatrze), który zdecydował o zainteresowaniach badawczych młodego naukowca i całej jego dalszej drodze, był Jerzy Grotowski. Drugą stronę tego filologicznego porządku stanowił więc żywioł rzeczywistości, doświadczenie/doświadczanie jako integralna część poznania/ poznawania ludzi, materii teatru, historii, tradycji. Na polskim gruncie teatrologicznym nieprzypadkowo przecież Osiński uznawany jest za pioniera uprawiania historii teatru połączonej ściśle $\mathrm{z}$ antropologią kultury.

W Pamięci Reduty pisal, że to kontakty z Grotowskim i jego teatrem zainspirowały Go ok. 1963 roku do zajęcia się Redutą:

[...] jest to rodzaj opowieści o tym, jak z uplywem lat doświadczenie Reduty wpisywało się w moje doświadczenie, myślenie i odczuwanie, w moją biografię. Jest to zatem jednocześnie dzieło uczone (to znaczy mające odpowiadać standardom uprawianej przeze mnie profesji) $\mathrm{i}-\mathrm{w}$ najbardziej dosłownym tego słowa znaczeniu - osobiste. Jak zresztą oddzielić jedno od drugiego? [Osiński 2003: 7]

Oto więc życie i historia splecione w działaniu Badacza.

Podobnie zresztą było w przypadku Ireny i Tadeusza Byrskich, którym poświęcił wydaną w 2005 roku książkę Nazywat nas bratnim teatrem. Przyjaźn artystyczna Ireny i Tadeusza Byrskich z Jerzym Grotowskim. Byrskich znał z ich poznańskiego sezonu teatralnego 1958/1959, ale w odautorskiej nocie zamieszczonej w tym tomie napisal:

[...] to dla mnie powrót do tematu przyjaźni artystów. Zacząlem go drążyć we Wstępie do odnalezionej na początku lat osiemdziesiątych ubiegłego wieku korespondencji Mieczysława Limanowskiego i Juliusza Osterwy (Listy, PIW 1987). $\mathrm{Z}$ perspektywy lat widzę, że już tam zawierały się w zarodku zarówno opublikowana kilkanaście lat później Pamięć Reduty, jak i książka o przyjaźni artystycznej Ireny i Tadeusza Byrskich z Jerzym Grotowskim. [Osiński 2005: 281] 
Najważniejszą kategorią antropologicznej postawy Osińskiego jest więc chyba spotkanie - czasem oznaczające także przyjaźń. Dalej można jeszcze mówić o historii/pamięci/rekonstrukcji, a także odnotować uczestnictwo/obecność/świadectwo. Przede wszystkim znajdują one potwierdzenie w późniejszych książkach, a także objaśniają w pewien sposób poznańskie początki.

Kiedy w marcu 1959 roku student drugiego roku polonistyki, Osiński, przyszedł do klubu studenckiego Od Nowa na dyskusję publiczną poświęconą przedstawieniu Wesela w Teatrze Polskim w reżyserii Tadeusza Byrskiego, ze scenografią Piotra Potworowskiego i muzyką Tadeusza Szeligowskiego, nie wiedział jeszcze, że zostanie teatrologiem i że wykonał właśnie pierwszy krok w tym kierunku... Dyskusję zorganizowała Sekcja Teatralna Koła Polonistów UAM, której przewodniczył wówczas Milan Kwiatkowski, dwa lata starszy kolega Osińskiego ze studiów, później wieloletni kierownik literacki teatru w Gnieźnie i Teatru Nowego w Poznaniu. Burzliwa, całonocna dyskusja z udziałem „wszystkich ważnych osób”, m.in. także profesorów Szweykowskiego i Ziomka, jest pierwszym śladem istotnej pamięci teatru w młodzieńczych doświadczeniach Osińskiego. Przyjaźń z Kwiatkowskim, udział w pracach Sekcji Teatralnej i zainteresowanie sprawami teatralnymi wyznaczyły początek prac naukowych pod kierunkiem profesora Szweykowskiego. To w Poznaniu doszło też do tego najważniejszego spotkania z Grotowskim i jego Teatrem 13 Rzędów. Zdecydowało ono praktycznie o całej późniejszej drodze naukowej Osińskiego. W listopadzie 1962 roku do Poznania przyjechał na gościnne występy zespół Teatru Laboratorium 13 Rzędów z Opola ze spektaklem Akropolis według Wyspiańskiego. Występy poprzedziło publiczne spotkanie Grotowskiego (także w klubie studenckim Od Nowa), a po pierwszym przedstawieniu spotkał się on prywatnie z Osińskim i Kwiatkowskim (którzy zapewne występowali wówczas jako redaktorzy - lub przyszli, planowani redaktorzy - pisma „Proscenium”, a może po prostu zostali zarekomendowani jako przedstawiciele Sekcji Teatralnej Koła Polonistów). Grotowski krótko potem wystąpił z propozycją współpracy z młodym teatrologiem, która rozpoczęła się na początku 1963 roku. 
Warto przypomnieć, że nie była to pierwsza wizyta Grotowskiego w Poznaniu. Prezentował tu już wcześniej Orfeusza według Jeana Cocteau (1959) i wyreżyserował w Teatrze Polskim Fausta, we współpracy ze scenografem Piotrem Potworowskim (1960). Przedstawienia te nie zrobiły na Osińskim specjalnego wrażenia. W 1963 roku teatr Grotowskiego na występach gościnnych w Poznaniu wystawił Tragiczne dzieje doktora Fausta według Christophera Marlowe'a; przy tej okazji odbyły się też spotkania ze środowiskami twórczymi Poznania w klubie w Arsenale i dyskusja o „sprawach warsztatu aktora i reżysera” - dyskusja bardzo burzliwa, wyrażająca sprzeciw (głównie środowiska teatralnego) wobec zjawiska, o którym mówiono, że „to już nie jest teatr”. Spektakl obejrzał także profesor Szweykowski i doszło wówczas do zainicjowanego przez Osińskiego spotkania Grotowskiego z profesorem w jego mieszkaniu. Podczas rozmowy, której przysłuchiwał się młody badacz, zafascynowany aurą spotkania i postawą siedemdziesięcioletniego już wówczas profesora, doszło do jego porozumieniu z trzydziestoletnim Grotowskim. W swoim komentarzu do tego wydarzenia notował Osiński znamienne uwagi:

[...] Doświadczyłem wówczas, że młodość duchowa nie ma nic wspólnego z wiekiem biologicznym. Ta lekcja pozostała we mnie na całe życie. [...] Zrozumiałem wtedy raz na zawsze, że istotne porozumienie między ludźmi wcale nie musi być związane z wiekiem, a uzależnianie go wyłącznie od doświadczeń pokoleniowych, co wówczas było modne, jest niczym innym, jak tworzeniem nowej mitologii. [Osiński 2013: 21-22]

Ziomek zwykł był powtarzać coś, jak mi się wydaje, współbrzmiącego z tym wyznaniem: różnice pokoleń to rzecz oczywista, ale nie musi wcale oznaczać konfliktu pokoleń.

Poznań Osińskiego to także szczególna przestrzeń. Trzeba uświadomić sobie topografię ówczesnego miasta, zobaczyć wszystkich tych ludzi w miejscach, które tworzyli, którym nadawali charakter i które ich określały. Wielu z tych miejsc już nie ma... Nie tak wielki wówczas Poznań (w latach 6o. - ok. czterystutysięczne miasto) wszystkie ważniejsze instytucje skoncentro- 
wał w centrum; także te nieoficjalne, funkcjonujące spontanicznie na mocy ludzkich przyzwyczajeń i upodobań (zawodowych i prywatnych). Topografia towarzysko-artystyczno-intelektualna ówczesnego Poznania obejmowała miejsca biesiadne, jak kawiarnie: Pół Czarnej (w pobliżu Collegium Philosophicum), Teatralna, Wrzos, W-Z; restauracje: Smakosz (naprzeciwko Teatru Polskiego, ulubione miejsce aktorów, Stanisława Hebanowskiego i profesora Ziomka), czasem Moulin Rouge (wówczas przy ul. Kantaka), Dietetyczna przy ul. Armii Czerwonej (dziś Św. Marcin), gdzie można było tanio i smacznie zjeść. Spotkania poważne miały swoją osobną lokalizację: Empik, Zamek, Pałac Działyńskich (czwartki literackie), PTPN, Collegium Philosophicum (Koło Polonistów).

Najważniejszy jednak pozostawał klub studencki Od Nowa przy ul. Wielkiej, gdzie skupiało się i integrowało środowisko intelektualno-artystyczne (uczelnie: UAM i PWSsP, także aktorzy teatrów Polskiego i Nowego, reżyserzy i scenografowie). Genius loci tej tzw. „starej” Od Nowy jest czymś niewątpliwym i historycznie zaświadczonym [zob. Książkiewicz-Bartkowiak, red. i oprac. 2011]. Kiedy w 1970 roku klub przeniesiono do Zamku, nie odgrywał już tak ważnej roli. Klub łączył funkcję zabawy z intelektualnymi atrakcjami „rozmów istotnych”, a - według cennych uwag Balcerzana - Poznań ówczesny charakteryzował się szczególną polifonią:

[...] identycznie splecione żywioły mobilizowały poczynania środowisk akademickich i artystycznych, nic dziwnego, że środowiska te zaczęły traktować instytucję [klubu - E.K.K.] Od Nowa jako własne centrum. Jako model kultury kompletnej.

Tu rzeczywiście dokonywała się integracja różnych środowisk. Odbywały się interdyscyplinarne spotkania: lekarza z prawnikiem, polonistą, historykiem sztuki, psychologiem, artysty z profesorem uniwersytetu czy studentem. Bywali tu ważni dla Osińskiego wybitni profesorowie: historyk sztuki Zdzisław Kępiński, prawnik Czesław Znamierowski. Bywali artyści miejscowi i przyjezdni, nauczyciele, działacze kultury, inteligencja. 
W Od Nowie Osiński brał udział w kilku edycjach gazety mówionej „Struktury”, prowadził spotkania z ludźmi teatru, m.in. z Konradem Swinarskim (1968, styczeń), Tadeuszem Kantorem (koniec 1968 roku), uczestniczył w klubowych imprezach. Tutaj także spotkał studencki Teatr Ósmego Dnia, z którym podjął współpracę w 1966 roku i wyreżyserował Warszawiankę według Wyspiańskiego na podstawie własnego scenariusza. Przy tej okazji zapoznał zespół z nowymi metodami pracy z aktorem i wprowadził elementy treningu aktorskiego, które sam poznał w Teatrze Laboratorium 13 Rzędów. Premiera odbyła się w kwietniu 1967 roku. Próby rozpoczęte w klubie przeniosły się rychło do miasta (z pomocą przyszła RSW Prasa przy ul. Grunwaldzkiej, udostępniając zespołowi salę konferencyjną), zaś premierowe przedstawienie miało miejsce w auli Pwssp. Ta Warszawianka była ponadczasową, uniwersalną opowieścią o wszystkich polskich powstaniach, wysyłaniu na śmierć całych pokoleń, o odpowiedzialności przywódców. Wydarzenie szeroko komentowano, miało zresztą swoich zwolenników i równie gorących przeciwników. Stanowiło niewątpliwie demonstrację nowego, innego myślenia o teatrze i próbę aktorstwa, którego ekspresja zbudowana była na młodości i braku zawodowej rutyny.

Ostatnia aktywność Zbyszka w „starej” Od Nowie w kwietniu 1970 roku miała szczególny charakter: była to dwudniowa sesja naukowa poświęcona wybranym problemom sztuki teatru, z udziałem m.in. profesor Ireny Sławińskiej, Ludwika Flaszena, Janusza Deglera, Lidii Kuchtówny, Sławomira Świontka, młodych pracowników nauki, członków zespołu Teatru Ósmego Dnia. Pokłosiem tego spotkania była książka zbiorowa $Z$ teorii teatru. Materiały sesji teatralnej, pod redakcją Osińskiego, wydana przez Centralny Ośrodek Metodyki Upowszechniania Kultury (Warszawa 1972). W ten sposób niejako symbolicznie dokonało się rozstanie Zbyszka z Poznaniem - i wejście w nową geografię praktykowania humanistyki (Warszawa, Wrocław, Kraków, podróże włoskie, wyprawy z Gardzienicami). Sam Zbyszek swoje wspomnienia o klubie zakończył w ten sposób:

Spoglądając po tylu latach na moje ówczesne wizyty w Od Nowie, widzę, że te spotkania sprzed 40 czy 50 lat są nadal 
we mnie obecne. W niemałym stopniu zadecydowały one o mojej drodze życiowej i dokonywanych wyborach. Z pewnością było $\mathrm{w}$ tym sporo młodzieńczego idealizmu i właściwych mu złudzeń, a jednak mam poczucie tożsamości i zgody z sobą samym z tamtych lat. Ostatecznie jest to połączone z poczuciem sensu, jakiegoś smaku życia i nieroztrwonionej na drobne młodości. [Osiński 2011: 66]

Intensywność życia artystyczno-intelektualnego niewątpliwie rekompensowała ubóstwo tamtej rzeczywistości, nadawała sens, pozwalała wbrew cenzurze i ideologii realizować marzenia. Nie powinno więc dziwić, że Osiński został recenzentem teatralnym nowego miesięcznika społeczno-kulturalnego „Nurt” (ukazywał się od maja 1965 do grudnia 1989 roku). Redaktorem naczelnym w pierwszym okresie był Krzysztof Kostyrko, a celem ówczesnej redakcji była integracja środowisk twórczych Poznania i Wielkopolski i ich prezentacja na forum ogólnopolskim. W inauguracyjnym numerze z 1965 roku znalazło się omówienie działalności Teatru 5 Stanisława Hebanowskiego autorstwa Osińskiego. Później Zbyszek regularnie pisywał do „Nurtu” recenzje z przedstawień wystawianych $\mathrm{w}$ poznańskich teatrach, publikował także inne formy dotyczące spraw teatralnych, np. wywiady - z reżyserem Jerzym Hoffmanem i Jerzym Ziomkiem o teatrze w Zielonej Górze czy z Grotowskim o festiwalu teatralnym w Kaliszu w roku 1967 (a zapewne mało komu przyszłoby dziś do głowy, że na tym festiwalu Grotowski był przewodniczącym jury konkursowego...).

Nie ma obiektywnej pamięci, pamięć jest zawsze zsubiektywizowana i zindywidualizowana. Zwłaszcza w sytuacji, kiedy żyjący rozprawiają o już nieżyjącym. Jednak możemy się przecież odwołać do poglądów Osińskiego w tej materii. W Spotkaniach z Jerzym Grotowskim... wyznaje, że pamięć jest dla Niego przede wszystkim zadaniem do wykonania. I przywołuje pojęcie długu w takim znaczeniu, jak rozumiał je Paul Ricoeur [2006: 117]: „[...] idea długu nierozerwalnie wiąże się z ideą dziedzictwa. Jesteśmy dłużni wobec tych, którzy nas poprzedzali w tym, czym jesteśmy”. 


\section{Ryszard K. Przybylski, Ocalajaca moc teorii}

W 1966 roku w zeszycie trzecim „Zagadnień Rodzajów Literackich” opublikowano artykuł autorstwa Edwarda Balcerzana i Zbigniewa Osińskiego zatytułowany Spektakl teatralny w świetle teorii informacji. Tekst ukazał się w wersji niemieckojęzycznej w tłumaczeniu Huberta Orłowskiego. O znaczeniu tej rozprawy w historii polskiej teatrologii świadczy bez wątpienia fakt jej kolejnych przedruków w antologii Problemy teorii dramatu i teatru redagowanej przez Janusza Deglera (najnowsze wydanie: Wrocław 2003). Aby rozpoznać innowacyjny charakter projektu poznańskich badaczy, warto powrócić na chwilę do momentu jego tworzenia.

Wszystko wskazuje na to, że artykuł powstawał w czasie, gdy Osiński i Balcerzan finalizowali swoje doktoraty bądź zaraz po ich ukończeniu. W mojej pamięci, choć rozpocząłem studia dopiero w 1967 roku, rysują się jako ci badacze, którzy reprezentowali to, co nowe w ówczesnej humanistyce. Rzecz jasna, chodziło o strukturalizm, ale nie tylko w jego wąskim, językoznawczym ujęciu, lecz także pojmowanym rozlegle, mającym zatem odniesienia do antropologii. Zresztą to czas zwycięskiej ofensywy strukturalizmu również w innych ośrodkach uniwersyteckich. My, studenci, mieliśmy świadomość, że Balcerzan i Osiński stali w pierwszym szeregu tego natarcia. Można by więc sądzić, że artykuł o spektaklu teatralnym będzie zanurzony w strukturalistycznej teorii, że zaroi się w nim od jej specjalistycznego żargonu. Ale nic z tego, zgodnie z tytułem lokuje się on w obszarze zagospodarowanym przez teorię informacji. Oczywiście, gdyby umieścić w chmurze pojęcia powiązane ze strukturalistycznym systemem, okazałoby się, że nie jest ich tak mało. Są wśród nich tak fundamentalne dla modelu komunikacji, jak: nadawca, komunikat, odbiorca, a dalej kody, subkody, substytucja, no i, oczywiście, pojęcie najważniejsze: struktura! Od razu warto jednak odnotować, że wpisanie rozważań w obszar teorii informacji nie prowadzi bynajmniej do zdrady strukturalizmu. Ostatecznie Umberto Eco również swe strukturalistyczne modele wizualności rozpoczyna od opisu teorioinformacyjnego systemu. Zatem także w przypadku Osińskiego i Balcerzana nie chodziło 
o konkurencyjną wobec strukturalizmu metodę. Dlaczego więc „spektakl teatralny w świetle teorii informacji”?

Powróćmy raz jeszcze myślą do roku 1966. Strukturalizm jawił się wówczas jako jeden ze sposobów przeciwstawienia się zarówno szeleszczącym anachronizmem genetycznym metodom badawczym, jak i doktrynerskim ujęciom marksistowskim. Strukturalizm oferował nowy słownik, pozwalający na alternatywne wobec nich możliwości opisu zjawisk kulturowych. Bez wątpienia metoda ta posłużyła do oryginalnych rozpoznań wielu, także dotąd omijanych w refleksji badawczej, zjawisk. Nie mniej wtedy jeszcze, w 1966 roku, przynajmniej w nadwarciańskiej przestrzeni, próżno szukać tak finezyjnych prób strukturalistycznego opisu przeróżnych kulturowych osobliwości, jakie przedstawił choćby w swych Mitologiach Roland Barthes. Był to raczej czas konstruowania słownika i sprawdzania jego użyteczności w odniesieniu do przedmiotu badań.

Dzieło sztuki teatralnej zaś, w porównaniu z literaturą, rysowało się jako mniej wyraziste, mniej konstrukcyjnie stabilne, płynne w swej naturze. Wnoszę więc, że autorzy artykułu, mając te okoliczności na uwadze, woleli sięgnąć po trochę inną teorię, trochę inny słownik, który podobną zmienność uwzględnia, więcej nawet - czyni z niej istotny element systemu. A że padło na teorię informacji? Nic w tym zaskakującego. Wtedy, w czasie powstawania artykułu, teoria informacji cieszyła się także sporą popularnością, a książka Norberta Wienera Człowiek i spoteczeństwo miała już dwa polskie wydania. Nadto profesor Jerzy Ziomek w 1965 roku opublikował „próbę zastosowania teorii informacji w badaniach nad przekładem" (to podtytul) w książce Staff $i$ Kochanowski... Można więc podejrzewać, że Osiński i Balcerzan podążyli tropem wskazanym przez starszego kolegę, a nawet byli przez niego zachęcani, aby pójść właśnie tą ścieżką badawczą. Nie ulega wątpliwości, że toczyły się dyskusje dotyczące ich artykułu. Dowodem na to może być publikacja Ziomka [1967] zamieszczona w „Dialogu” w 1967 roku, zatytułowana Aktor w systemie znaków, która, notabene, znalazła po latach rozwinięcie w tekście Semiotyczne problemy sztuki teatru [Ziomek 1976]. Dla Ziomka „w sztuce teatru najważniejszy jest aktor”. Takie stwierdzenie brzmi jak głos w dys- 
kusji nad tekstem Osińskiego i Balcerzana. Nie jest tak, by oni uważali inaczej, ale w ich ujęciu aktor został ulokowany, rozproszony wśród innych znaków. Mówiąc obrazowo, jakby zagubił się w tłumie, w którym błąkałby się odtąd między reżyserem, autorem, scenografem, inspicjentem, muzykiem czy operatorem świateł. Wszyscy ci udziałowcy, sprawcy teatralnego wydarzenia, zostali zaliczeni zaś do Zespołu Nadawcy. Taka kategoryzacja wydaje się w pełni uzasadniona, jeśli po drugiej stronie relacji ulokuje się, tak samo zbiorowy jak w układzie nadawczym, Zespół Odbiorcy. Ów zbiorowy charakter Nadawcy i Odbiorcy zdaje się w pełni uzasadniać wybór teorioinformacyjnego modelu opisu zjawisk, a tym samym rezygnację $\mathrm{z}$ korzystania ze strukturalistycznego modelu komunikacji. Tym bardziej, że teatralny spektakl realizuje się $\mathrm{w}$ interakcji z widownią. Autorzy prezentowanego artykułu drobiazgowo omówili przebiegi oddziaływania na siebie zespołów Nadawcy i Odbiorcy, by w konsekwencji wyróżnić, będące tego efektem, trzy typy scenicznego Komunikatu; przy czym nie chodzi tu o jedną jego konkretyzację, a o serię następujących po sobie przedstawień. W pierwszym $\mathrm{z}$ nich będziemy mieć do czynienia z dążeniem do utrzymania stanu względnej równowagi wobec premierowej normy, $\mathrm{w}$ drugim - z potęgowaniem się stanu nieporządku w stosunku do wyjściowych założeń, a w trzecim $\mathrm{z}$,dewiacyjnym” konstruowaniem nowych wytycznych w odniesieniu do pierwotnej realizacji. Mamy więc tu do czynienia nie z procesem strukturyzacji i restrukturyzacji jako immanentną cechą samej struktury, ale z udziałem zewnętrznych czynników stymulujących zmianę w określonym układzie.

Ale to niejedyne uzasadnienie dokonanych przez Balcerzana i Osińskiego metodologicznych wyborów. Wykorzystanie teorii informacji w charakterystyce spektaklu teatralnego wychodziło, moim zdaniem, także naprzeciw dominującym wówczas praktykom teatralnym. Oczywiście chodziło o ogląd krytyczny. Powojenny Poznań nie miał wówczas specjalnych powodów do dumy, ostatecznie klątwa Wilama Horzycy miała jakieś podstawy, a niemożność zatrzymania się tutaj na dłużej Ireny i Tadeusza Byrskich zdawała się to tylko potwierdzać. Jednak i w Polsce niełatwo było o olśnienia. Dla oczekujących od sztuki czegoś więcej 
niż tylko zaspokojenia drobnomieszczańskich estetycznych oczekiwań podjęcie próby teoretycznego przemyślenia istoty teatru wydaje się w pełni zrozumiałe. Tym bardziej, gdy kierunek refleksji wyznaczyć mają uczestnicy Wielkiej Reformy Teatralnej oraz jej współcześni kontynuatorzy: Tadeusz Kantor i Jerzy Grotowski. To właśnie w tym horyzoncie ulokowany został dyskurs młodych wówczas badaczy. Tak silne wyodrębnienie dwóch ensembli, jakimi według nich pozostają w istocie Zespoły Nadawcy i Odbiorcy, pozwala na uwzględnienie zmiennych, które nie tylko wpływają na określony kształt przedstawienia, lecz także otwierają nowe możliwości dla nowych konceptualizacji sztuki teatru. Podobnie było w czasach Wielkiej Reformy, gdy swoje realizacje prezentowali Wsiewołod Meyerhold, Erwin Piscator czy w Polsce Leon Schiller, a współcześnie także Cricot 2 czy Teatr 13 Rzędów lub Teatr Laboratorium. Granie spektaklu wśród widzów z jednej strony jest propozycją nowej formy ich uczestnictwa, z drugiej zaś daje reżyserowi sposobność organizowania nie tylko zespołu aktorskiego, ale i teatralnej publiczności.

Konkludując, warto podkreślić, że artykuł Balcerzana i Osińskiego bardzo efektownie i skutecznie zakwestionował obowiązujące wtedy jeszcze na gruncie teatrologii praktyki, według których należało badać stosunek dramatu do jego realizacji scenicznej. Według omawianych autorów tzw. teatralna teoria dramatu kończy się niemal zawsze w koleinach „literackiej teorii teatru”. Konieczne więc było otwarcie nowej drogi.

Edward Balcerzan: Ponieważ ongiś w naszym gronie wybuchały gorące spory na temat rozmaitych koncepcji badawczych, zarówno oryginalnych, jak i podpatrzonych u innych znawców - sądziłem, że profesor Przybylski podda nasz dawny artykuł miażdżącej krytyce... Tymczasem bardzo empatycznie go przeanalizowal, za co dziękuję. Nie będę się już więc odnosił bezpośrednio do tekstu, ale dopowiem kilka uwag kontekstowych, bo okoliczności powstawania artykułów także coś mówią o ich ukierunkowaniu. 
Zbyszek miał zawsze bardzo silną potrzebę nie tyle buntu, ile awangardyzmu, która nie była jednak nastawiona na negację i niszczenie, lecz na stwarzanie czegoś nowego, własnego, innego; reprezentował więc nie postawę destrukcyjną, lecz porządkującą. (To nas do siebie zbliżało). Rzecz w tym, że charakter badawczego porządkowania sztuki pojmowano rozmaicie, zarówno w Instytucie, jak i w całym środowisku polonistycznym. Stanowiło to źródło długotrwałych polemik. Szczególną wyrazistością odznaczały się wówczas poglądy profesora Jarosława Maciejewskiego i jego niesłychanie zdolnego ucznia, Andrzeja Wanata - i Zbyszek często i z ochotą wchodził z nimi w spory. Dla Maciejewskiego i Wanata teatr był nieodmiennie częścią współczesności postrzeganej politycznie, narodowo, obyczajowo; był zawsze miejscem wypowiedzi na tematy aktualne, jak mówił Maciejewski: miejscem „robienia aluzji”. Wiersz, dramat, spektakl stanowily w ich ujęciu zbiory przypisów do współczesności - kiedy Wanat mówił o Wyspiańskim na scenie, traktowal dane zdarzenie sceniczne jako wypowiedź o tym, co dzieje się dziś. Dla Zbyszka natomiast odniesienia współczesne stanowiły element zdecydowanie mniej istotny: ważny był wymiar antropologiczny czy metafizyczny, a więc to, co w teatrze jest arcyludzkie, uniwersalne, mierzące się z istotą człowieczeństwa; dlatego tak blisko mu było do Grotowskiego. Kiedy więc Zbyszek zaproponowal, żebyśmy - wykorzystując kategorie cybernetyki i teorii informacji - razem napisali artykul, nie kryłem zaskoczenia. Nie podejrzewałem, że może go zainspirować cokolwiek z kręgu wiedzy o maszynach, automatach, rakietach, wiedzy bliższej fizyce niż metafizyce. Gdy dziś o tym myślę, przeglądając raz jeszcze słownik terminów, którymi się wtedy posługiwaliśmy (Ryszard pięknie je wyłowił w swoim referacie), dochodzę do wniosku, że najważniejsze dla wielbiciela Wilama Horzycy, Jerzego Grotowskiego i Konrada Swinarskiego mogły być wówczas dwa pojęcia: sprzężenie zwrotne i entropia.

Za pomocą „sprzężenia zwrotnego” mógł opisywać teatr jako spotkanie, dialog, rozmowę - jednym słowem: taką konstrukcję, która eliminowała możliwość zaistnienia „czwartej ściany”, zapobiegała izolowaniu sceny od widowni. To właśnie znalazł 
u Grotowskiego (prawem dygresji trzeba zauważyć, że u Grotowskiego akurat bywało różnie: w Akropolis aktorzy wprawdzie dreptali, jęczeli, ciągnęli taczki tuż obok widza, ale go przecież nie „zauważali”, choć jednocześnie widz miał wrażenie, że jest jednym z nich...). „Sprzężenie zwrotne” pozwalało Zbyszkowi, jak sądzę, świeżym językiem wyjaśniać interakcyjny, dialogowy charakter spektaklu. Natomiast „entropia” - jak u Norberta Wienera, który sugestywnie nazwał informację „wysepką w oceanie entropii” stała się atrakcyjną metaforą losu nowatorstwa, działań awangardowych - w sztuce i w refleksji nad sztuką. Być może Zbyszek widział to wówczas tak, że oto my, towarzyszący awangardom xx wieku, razem z nowatorami próbujemy ocalać cząstki informacji, drobiny wyższego sensu, w świecie osaczonym przez informacyjny bezład.

Pierwszym miejscem druku Spektaklu wświetle teorii informacji stał się zeszyt ambitnej serii teoretycznej „Zagadnienia Rodzajów Literackich”, zamieszczającej prace wielojęzyczne. Zwróciliśmy się z prośbą o przekład na język niemiecki do germanisty, kolegi-rówieśnika, naszego serdecznego przyjaciela, Huberta Orłowskiego. Bardzo się i jemu, i nam spodobało to przymierze. Wyznam, że przeżywaliśmy (po cichu) nasz trzyosobowy wysiłek jako próbę małego manifestu pokoleniowego... Nie eliminowało to różnic między nami - w pojmowaniu tego, czym jest tekst naukowy. Zbyszek uważał, że taki tekst musi odznaczać się przede wszystkim solidnym warsztatem dokumentacyjnym; podobnie chyba myślał Hubert, jak można wnioskować $\mathrm{z}$ wielu jego prac późniejszych; $\mathrm{z}$ kolei dla mnie zadanie polegało na odnalezieniu w miarę precyzyjnego (nieimpresyjnego) języka, który by nas, humanistów, wyzwalał z kompleksów wobec nauk przyrodniczych czy matematycznych. Nie sądzę zresztą, by wybrany przez nas język aż tak bardzo się zestarzał. Pojęcia, które wówczas wykorzystaliśmy (do wymienionych dodałbym pożyteczne rozróżnienie „krótkiej i długiej histerezy”), weszły do obiegu humanistyki i były intensywnie używane, a nasz tekst wpisywał się tym sposobem w nowoczesny dyskurs naukowy. Zależało nam na tym, żeby obraz spektaklu okazał się empirycznie sprawdzalny, a zarazem innowacyjny (napisany niestaroświecką polszczyzną naukową). Chcieli- 
śmy pokazać, że humanistyka nie jest natchnioną retoryką, lecz przeprowadza dowody wynikające $\mathrm{z}$ konkretnych badań i w ten sposób służy przyrostowi wiedzy.

Ryszard K. Przybylski: Ten tekst jest nawet, moim zdaniem, w jakiejś mierze wciąż aktualny, a to dlatego, że nie zamknął możliwości refleksji nad teatrem na proponowanej ścieżce, czyli analizie relacji (poprzez sprzężenie zwrotne) między jednym a drugim zespołem i wpływie tego układu na wytwarzany komunikat. Wprawdzie istnieje $\mathrm{w}$ artykule dążenie do tego, żeby ten komunikat ustabilizować, uporządkować jego elementy, ustrukturyzować, ale nie - unieruchomić; mam wrażenie, że podążając tą ścieżką, moglibyśmy przez semiologię dojść do zwrotu performatywnego.

Kiedy profesor Jerzy Ziomek pisał w połowie lat 70. artykuły poświęcone semiotycznym ujęciom teatru, poruszał się już w obrębie nowego języka naukowego, wprowadzał nowe pojęcia. U schyłku lat 6o. mówiło się jeszcze o „subkodach”, a Ziomek mówił już innym językiem; np. w waszym artykule mowa jeszcze o „języku”, a u Ziomka mówi się już o „tekście teatralnym”. To pokazuje, że w zasadzie da się „podmienić” terminy, nie tracąc zasadniczego tematu. Niemniej jest coś, co te teksty zasadniczo różni: w Spektaklu teatralnym dominuje problem relacyjny i zadanie wykazania, jak te dwie instancje, nadawcza i odbiorcza, wzajemnie się warunkują, zaś Ziomek upomina się o aktora, stara się go wynieść i dowartościować, sięga nawet do argumentów Wielkiej Reformy i Craigowskiej nadmarionety. Ale poza tą różnicą (czyli zdecydowaną fascynacją Ziomka aktorem) widać, że wasz tekst może wciąż w pewien sposób „pracować” - bo zawsze dochodzimy do procesu performowania.

Edward Balcerzan: Kiedy Zbyszek zaczął „chłonąć” Grotowskiego, niestrudzenie jeździł, oglądał, przeżywal, spotykał się z nowymi ludźmi - i gdy wracał ze swoich wypraw, musiał komuś o nich opowiedzieć; bardzo chciał podzielić się doświadczeniami i wrażeniami. Ale właściwie On nie opowiadał - tylko ponownie tam „byl”, grał całym sobą, właśnie performował - nierzadko zadziwiając postronnych obserwatorów... 
Piotr Frydryszek: ...bo przecież Zbyszka cechowała niezwykła fizyczność, a jego sposób funkcjonowania to był właściwie pewien fenomen. Wielu młodszych kolegów (i tylko kolegów to dotyczyło, koleżanek nie) upodabniało się do niego w gestykulacji, w pochyleniu sylwetki, sposobie chodzenia, zakładania do tyłu rąk (czasem niósł w nich jeszcze teczkę) - to było najwyraźniej zaraźliwe. Mnie samego zafascynowała w Zbyszku Jego „wielość”, to nie był człowiek jednowymiarowy, w dodatku była w Nim jakaś zagadka. Rozwichrzony, roztargniony, trochę chaotyczny - był zarazem nadzwyczaj skrupulatny, uporządkowany i bardzo uważny. Poznałem Go na studiach, prowadził z nami zajęcia z poetyki; do dziś pamiętam Jego niezwykły sposób myślenia, osobowość - i właśnie ów niecodzienny sposób bycia. Gdy zapytano mnie kiedyś w medialnej ankiecie o ludzi, którzy wywarli na mnie największy wpływ, na pierwszym miejscu wymieniłem Zbyszka.

Dobrochna Ratajczakowa: A czy nie sądzi pan, że źródłem tej fascynacji Zbyszkiem mogła być także jego niezwykła, autentyczna zdolność do głębokiego przeżywania międzyludzkich kontaktów i zdolność do całkowitego zafascynowania kimś (lub czymś)?

Piotr Frydryszek: Tak, bo Zbyszek rzeczywiście „był całym sobą” i każdego, kto znalazł się w Jego orbicie, po prostu wchłaniał, przyciągał... to właśnie w skrajnych przypadkach znajdowało wyraz w przejmowaniu przez innych Jego sposobu poruszania się, mówienia...

Elżbieta Kalemba-Kasprzak: ...co można by opisać za pomocą kinestezji; takie zjawisko fizycznego przyciągania, mocy oddziaływania gestu, fascynacji, stanowiącej subiektywne i unikatowe sensoryczne doświadczenie.

Edward Balcerzan: I warto przypomnieć, że przecież Zbyszek był w młodości sportowcem, uprawiał biegi na średnich dystansach, co potem zaowocowało w dorosłym życiu upodobaniem do długich spacerów i do intensywnego ruchu. 
Piotr Frydryszek: I wcale na początku nie był pewien, czy wybrać karierę sportowca, czy naukowca, zwłaszcza że pochodził z bardzo usportowionej rodziny: obaj jego bracia uprawiali skok o tyczce.

Katarzyna Osińska: A jeden z nich, Włodzimierz Osiński, był nawet dwukrotnym rekordzistą i wicemistrzem Polski w tej dyscyplinie.

Lech Raczak: Skoro jesteśmy przy fizyczności Zbyszka, to dołączę z takim obrazem: kiedy na początku lat 90., po powrocie $\mathrm{z}$ emigracji, pojechałem do Warszawy, by spotkać się ze Zbyszkiem, zmierzałem Krakowskim Przedmieściem na Uniwersytet - i zobaczyłem, że z bramy uniwersyteckiej wychodzą dwaj studenci: obaj charakterystycznie pochyleni, teczki trzymali z tyłu... Pomyślałem wtedy: jest dobrze, Zbyszek nadal tu wykłada i najwyraźniej jest w świetnej formie.

Poznałem Go, oczywiście, w Poznaniu, w roku 1966, na studiach polonistycznych. Razem z kolegami założyliśmy wówczas Studencki Teatr Poezji, zagraliśmy parę przedstawień; na jedno z nich przyszedł Osiński - i bodaj coś w nas dostrzegł, bo złożył propozycję wspólnej pracy. Wybrał parę osób (wszyscy żyjący z tej grupy - czyli cztery osoby - są dziś tutaj: Elżbieta Kalemba-Kasprzak, Janina Karasińska, Piotr Frydryszek i ja) i po kilku sesjach rozwijających ćwiczeń fizycznych i głosowych zaproponował nam realizację Warszawianki według Wyspiańskiego. Wedługbo ta Warszawianka nie miała w żaden sposób nawiązywać do dotychczasowych przedstawień scenicznych tego dramatu, miała natomiast wprost odnosić się do pracy Grotowskiego; rzecz miała się dziać właściwie poza czasem, przywoływać powstanie, ale nie to konkretne, z dramatu, lecz wszystkie polskie powstania naraz, zachować pewien misteryjny charakter - dlatego właściwszy tytuł tego przedstawienia brzmiałby raczej Historia wyniesienia i upadku wodza. Podstawę struktury spektaklu tworzyły kombatanckie, historyczne pieśni: za Warszawianką szły inne z XIX i XX wieku, aż do $O$ mój rozmarynie i podobnych pieśni wojennych - które kontrastowały z tekstem Wyspiańskiego. Nauczyliśmy się też wtedy od Zbyszka, że to, co nieestetyczne, ma czasami zdecydowanie 
bardziej uderzający walor estetyczny: myśmy mianowicie te pieśni chrypieli, tupaliśmy głośno buciskami, odziani byliśmy w osobliwe kostiumy z nadpalonych plastikowych płacht (wymyślał je nasz scenograf, Witold Wąsik). W dodatku byliśmy bardzo młodzi, mieliśmy po dwadzieścia lat; w odbiorcach przyzwyczajonych do bardziej klasycznych wykonań musiało budzić opór, że Chłopicki (którego grałem) był po prostu szczeniakiem... ale wiek wykonawców doskonale zgadzał się przecież z poczuciem, które dzielimy wszyscy: że do wszystkich tych powstań i rebelii szli zawsze ludzie bardzo młodzi. I to chyba zagrało, nawet jeśli nie było przez Osińskiego w ogóle zamierzone. W Poznaniu Warszawianka okazała się wydarzeniem dość dwuznacznym: część publiczności przyjęła ten spektakl znakomicie, nawet jak rodzaj teatralnego objawienia; byli tacy, którzy przychodzili na wszystkie przedstawienia, ale część starych koneserów kręciła nosami: że aktorzy grają za blisko publiczności, że nieestetycznie, że mało w tym w ogóle teatru... Bo faktycznie: „teatru” w sensie klasycznym było mało. Natomiast dla mnie było to bardzo ważne i formujące doświadczenie. Zrozumiałem przy okazji, że trzeba częściej zaglądać do biblioteki, więcej czytać, zgłębiać lektury i teorie, a jeśli nie ma stosownych tłumaczeń, to przedzierać się przez oryginały (jak było w moim przypadku z Fiodorem Dostojewskim) - tego wszystkiego nauczył mnie Zbyszek i bardzo to doceniałem. Jednak kiedy parę lat później, na seminarium magisterskim u profesora Jerzego Ziomka zaproponowałem, że napiszę pracę magisterską o Grotowskim i profesor zareagowal przychylnie - to postanowiłem zataić ten fakt przed Osińskim... Obawiałem się po prostu, że jeśli mu powiem, to Zbyszek zmusi mnie do napisania o Grotowskim tak, jak sam Go widział, a ja chciałem napisać po swojemu. Zapewne moja praca przez brak kontaktu z Osińskim wiele straciła, ale ja sam wiele zyskałem: np. samodzielność i niezależność sądów. I potem, po latach, kiedy już się przyjaźniliśmy, zauważyłem, że w jednej ze swoich książek mnie zacytował... czyli dotarł do tej pracy i uznał mój punkt widzenia.

Trochę na prawach anegdoty wspomnę, że w latach 6o., kiedy zaczynaliśmy studia, panował obyczaj mówienia sobie per „pan”. To pozornie tylko szczegół, a w rzeczywistości ważna rzecz: przej- 
ście z mocno gombrowiczowskiej szkoły na uczelnię natychmiast zmieniało status - skoro wszyscy mówili do człowieka „pan”, to znaczyło, że traktują go poważnie, że zostawał partnerem w rozmowie. Ale w konsekwencji nawet podczas pracy nad spektaklem w co dziś trudno uwierzyć - nadal byliśmy z Osińskim na „pan” (mówiliśmy do niego: „panie doktorze”) i dopiero potem, kiedy już jeździliśmy na pokazy po Polsce, zaczęliśmy mówić sobie po imieniu. Niewykluczone jednak, że te początkowe oficjalne formy dodały powagi naszej pracy, narzuciły jej trochę inny charakter.

Pozostawaliśmy ze Zbyszkiem w przyjaźni przez wiele lat i bardzo często, właściwie przy niemal każdym spotkaniu, nieuchronnie rozmawialiśmy o Grotowskim, który przecież i w moim życiu odegrał wielką rolę, był dla mnie mistrzem i punktem odniesienia. Choć, trzeba przyznać, zdarzały się między nami napięcia, jak wtedy, gdy napisałem i opublikowałem paszkwil na parateatr a dotyczył on w znacznej mierze także Grotowskiego. Nastąpiła wtedy przerwa w spotkaniach, na szczęście krótka. A teraz, kiedy Zbyszka zabrakło, czuję straszny brak... Nie wiem, czy mam jeszcze po co jeździć do Warszawy, wraz z Nim umarła mi motywacja...

Piotr Frydryszek: Jeśli mówimy o Warszawiance, to trzeba koniecznie dodać, że był to przecież spektakl nader brzemienny w skutkach dla Teatru Ósmego Dnia; zmienił zupełnie dotychczasowy sposób funkcjonowania zespołu - bo mimo że po nim wystawiono jeszcze Edwarda II Marlowa (w reżyserii Tomasza Szymańskiego), to zaraz potem zaczęła się praca zupełnie innego rodzaju i późniejsza historia teatru potoczyła się nowym torem. Warszawianka w reżyserii Osińskiego była więc właściwie dla teatru przełomowa.

Lech Raczak: Może również stała się jakimś ważnym impulsem dla innych scen studenckich, bo przecież podczas pierwszych pokazów Warszawianki na festiwalu w Lublinie (na KUL) prosiliśmy organizatorów o zdemontowanie istniejącej tam tradycyjnej widowni, ponieważ potrzebowaliśmy zupełnie innego układu sali: używaliśmy własnego podestu i graliśmy blisko widzów. Kiedy gościliśmy tam drugi raz, z innym spektaklem - historia 
się powtórzyła. Ale za trzecim razem zastaliśmy salę z już zdemontowaną widownią, która nigdy nie wróciła do dawnej postaci. Nasza Warszawianka zapoczątkowała więc zmianę przestrzenną w eksperymentalnym teatrze w Polsce, a przynajmniej w teatrach studenckich.

Piotr Frydryszek: Poza tym jakoś utrwaliła - przynajmniej u nas status zespołu studenckiego. Zbyszek prowadził wówczas swoje poszukiwania $\mathrm{w}$ kręgu nieprofesjonalnym, czyli z nami, ale przecież w pierwszym zamyśle w roli Chłopickiego chciał obsadzić Henryka Machalicę, zawodowego aktora. Okazało się szybko, że to nie da się w żaden sposób skleić: aktor profesjonalny i aktor amator istnieli na scenie na zupełnie innych zasadach. Zbyszek szczęśliwie więc porzucił ten projekt, został przy amatorach z zyskiem dla całego zespołu. Może to jedyna okazja, by teraz przypomnieć, kto kogo grał: Lech Raczak, jako się rzekło, był Chłopickim, ja grałem Młodego Oficera, Janka Karasińska - Marię, Elżbieta Kalemba-Kasprzak - Annę, siostrę Marii. Pamiętam reakcję profesora Włodzimierza Dworzaczka na jedną ze scen - ślubu Młodego Oficera z Anną: profesor był wzruszony i poruszony, bo ten obraz skojarzył mu się (całkiem słusznie, bo właśnie tak był zaplanowany) ze ślubami zawieranymi w ruinach miasta przez powstańców warszawskich.

Janina Karasińska: Niemniej, o czym warto wspomnieć, zanim profesor przyszedł na spektakl, był jednak pełen wahań; wyznał w rozmowie ze mną (byłam jego seminarzystką): „[... ] słyszałem, że to jest bardziej Warszawianka pana Osińskiego niż Wyspiańskiego...”.

Lech Raczak: A czy Zbyszek widział Fausta Grotowskiego w Teatrze Polskim w Poznaniu?

Elżbieta Kalemba-Kasprzak: Widział, ale to Go nie zachwyciło, podobnie jak dwa inne przedstawienia, z którymi zespół Grotowskiego wcześniej przyjechał do Poznania. 
Piotr Frydryszek: Nie zachwyciło - czemu chyba nawet dał wyraz na piśmie, ponieważ nie zapominajmy, że Zbyszek był też wówczas w Poznaniu ważną postacią recenzencką; moim zdaniem nie mieliśmy już nigdy potem równie wyrazistego i ostrego recenzenta teatralnego jak wówczas Zbyszek...

Lech Raczak: ...co też było znakiem jego niesłychanego zaangażowania w to, co robił. Recenzje były ostre, bo Mu zależało. Słynna anegdota obrazująca możliwy stopień zaangażowania Zbyszka głosi, że podczas Jego wykładu na jednym z uniwersytetów we Włoszech nagle sala w mgnieniu oka opustoszała - a Zbyszek mówił dalej, w ogóle nie zauważając nie tylko ubytku słuchaczy, ale i przyczyny tego exodusu, którym było... trzęsienie ziemi; On jeden się nie ewakuowal.

Grzegorz Ziółkowski: Rozmawiamy o Osińskim poznańskim a tymczasem zawędrowaliśmy aż do Włoch. Po doświadczeniach innych miast i krajów Profesor wrócił do Poznania, o czym chcę przypomnieć: był przecież recenzentem doktoratu honorowego przyznanego przez Uniwersytet im. Adama Mickiewicza Peterowi Brookowi w roku 2005, co było też symbolicznym powrotem profesora Osińskiego na poznański uniwersytet.

Katarzyna Osińska: Bo Poznań był rzeczywiście dla Zbyszka bardzo ważny, a kiedy opowiadał mi o poznańskich latach, to zawsze wspominał swoich nauczycieli - profesora Zygmunta Szweykowskiego, profesora Ziomka, profesora Zdzisława Kępińskiego - co zresztą było częścią osobistego etosu Zbyszka, nakazującego zawsze pamiętać o przodkach, poprzednikach i nauczycielach. Mnóstwo mówił oczywiście o przyjaciołach z Teatru Ósmego Dnia, a także o Byrskich czy Stanisławie Hebanowskim. Istotnym miejscem - o czym wspominaliśmy - był też dla Niego klub Od Nowa; nazywał go zawsze swoim „drugim uniwersytetem” i bardzo ubolewał nad stopniowym znikaniem klubów studenckich - takich, w których koncentrowało się intelektualne i kulturalne życie młodej inteligencji, do których zapraszało się wybitnych ludzi nauki i sztuki. W poznańskiej Od Nowie nie tylko gościł 
Grotowski, ale bywali tu też Tadeusz Kantor, Konrad Swinarski, Henryk Tomaszewski, Miron Białoszewski. Zbyszek nawet prowadził niektóre z tych spotkań. Wiele wątków, które pojawiały się potem w Jego pracach, zawiązało się właśnie w Od Nowie. Wśród innych miejsc, które zawsze wymieniał, znalazła się też słynna restauracja Smakosz - znajdująca się ongiś naprzeciwko Teatru Polskiego i gromadząca wielu ludzi związanych z teatrem i uniwersytetem. Odkąd powstał festiwal Malta - Zbyszek przyjeżdżał do Poznania na każdą niemal edycję.

Ale Jego powroty - to nie tylko przyjazdy, wizyty i spotkania. Zbyszek całe życie prowadził notatki. Opisywał oczywiście skrupulatnie, o czym wszyscy wiedzą, swoje spotkania z Grotowskim, ale robił też nieustająco zapiski z innych spotkań i wydarzeń. Jakby zapisywał swoje życie, jakby chciał je utrwalić - ten swoisty przymus zapisywania czyni z Jego życia rodzaj egzystencjalnego projektu: nie pozwolić, żeby zniknęło. Dlatego tak często sięgał do przeszłości - jednak nie tylko pod koniec życia (w czym nie byłoby nic wyjątkowego: wielu ludzi zaczyna wtedy snuć wspomnienia); On robił tak zawsze i od zawsze. Może właśnie dzięki temu miał szczególnie wyostrzoną pamięć: Zbyszek, moim zdaniem, pamiętał o wiele więcej niż inni. I nie dotyczyło to tylko jakichś wyjątkowo ważnych wydarzeń, ale także drobnych aspektów życia... w odpowiednich momentach zawsze potrafił je wydobyć. Bardzo dziękuję, że na dzisiejszym spotkaniu my z kolei przypomnieliśmy i te drobne, i te bardzo istotne momenty poznańskiego okresu życia i pracy Zbyszka.

Seminarium moderowata i teksty zredagowała Ewa Guderian-Czaplińska

\section{Bibliografia}

Książkiewicz-Bartkowiak Danuta, red. i oprac. (2011), Klub „Od nowa” 1958-1970, Wydawnictwo Miejskie Posnania, Poznań.

Osiński Zbigniew (2003), Pamięć Reduty. Osterwa, Limanowski, Grotowski, Słowo/obraz terytoria, Gdańsk. 
Osiński Zbigniew (2005), Nazywat nas bratnim teatrem. Przyjaźń artystyczna Ireny i Tadeusza Byrskich z Jerzym Grotowskim, Słowo/ obraz terytoria, Gdańsk.

Osiński Zbigniew (2011), Zapiski z „Od Nowy” 1959-1970. Notatki ze spotkań z Jerzym Grotowskim i Tadeuszem Kantorem, w: Klub Od Nowa 1958-1970, red. i oprac. Danuta Książkiewicz-Bartkowiak, Wydawnictwo Miejskie Posnania, Poznań, s. 53-67.

Osiński Zbigniew (2013), Spotkania z Jerzym Grotowskim. Notatki, listy, studium, Słowo/obraz terytoria, Gdańsk.

Ricoeur Paul (2006), Pamięć, historia, zapomnienie, przeł. Janusz Margański, Universitas, Kraków.

Ziomek Jerzy (1967), Aktor w systemie znaków, „Dialog”, nr 9, s. 75-82.

Ziomek Jerzy (1976), Semiotyczne problemy sztuki teatru, „Teksty”, nr 2, s. 9-27.

\section{Osiński poznański. About the early stage of Zbigniew Osiński’s scientific work in Poznań}

The article is a record of a seminar meeting devoted to the memory of professor Zbigniew Osiński, an outstanding theatrologist, first director of the Grotowski Institute in Wrocław, a scholar interested in the works of Juliusz Osterwa, Jerzy Grotowski, Gardzienice Theater and Tadeusz and Irena Byrski's theatre; researcher of the Oriental theatre reception in Poland. The seminar was organized to commemorate the first death anniversary of the Professor whose scientific path began to take shape in Poznan where he worked until 1970. The record of the meeting reflects its course: in the first part, three short speeches were given: - Professor Dobrochna Ratajczakowa talks about the beginnings of Zbigniew Osiński's career as a researcher, Professor Elżbieta Kalemba-Kasprzak - about the 'practice of humanities' in a specific Poznań way, and professor Ryszard K. Przybylski - about the famous article that used information theory tools written by Balcerzan and Osiński. The second part is devoted to the memories of and reflections on the artistic and scientific activity of Professor Osiński in Poznań. Among the guests of the seminar were Professor Edward Balcerzan, Lech Raczak, Piotr Frydryszek, Janina Karasińska - friends and co-workers of Professor Osiński.

Keywords: Zbigniew Osiński; Jerzy Grotowski; Teatr Ósmego Dnia [Theatre of the Eighth Day]; theatre; science and artistic practice. 
Dobrochna Ratajczakowa - profesor doktor habilitowana, twórczyni poznańskiej teatrologii na Uniwersytecie im. Adama Mickiewicza w Poznaniu, wieloletnia (1996-2013) szefowa Zakładu Dramatu i Teatru, a później Katedry Dramatu, Teatru i Widowisk. Autorka wielu książek teatrologicznych, ponad dwustu artykułów naukowych, pomysłodawczyni serii wydawniczych „Kolekcja Teatralna”, „Theatroteka. Źródła i Materiały do Historii Teatru”, „Nowoczesna Myśl Teatralna”. Badaczka teatru i dramatu XVIII-XXI wieku. W 2006 roku ukazał się dwutomowy wybór jej najważniejszych artykułów pt. W krysztale i w ptomieniu. Studia i szkice o dramacie i teatrze. Ostatnio (2015) wydała leksykon Galeria gatunków widowiskowych, teatralnych $i$ dramatycznych.

Elżbieta Kalemba-Kasprzak - profesor UAM doktor habilitowana, teatrolożka i literaturoznawczyni, związana od 1975 roku z Wydziałem Filologii Polskiej i Klasycznej (gdzie pełniła m.in. funkcje wicedyrektora Instytutu Filologii Polskiej, prodziekana Wydziału, a w latach 2014-2017 dyrektorki Katedry, wkrótce przekształconej w Instytut Teatru i Sztuki Mediów). Poświęciła prace badawcze krytyce teatralnej (Teatr w gazecie), twórczości Stefana Żeromskiego (Prometeusz z przepiórka. Dramaty Stefana Żeromskiego: od Czarowica do Przetęckiego), a także - w osobnych artykułach - polskiej dramaturgii najnowszej czy wielu obszarom teatru postdramatycznego, w tym teatrowi tańca.

Ewa Guderian-Czaplińska - profesor UAM doktor habilitowana, w pracy badawczej i dydaktyce zajmuje się głównie teatrem dwudziestolecia międzywojennego oraz krytyką teatralną (w jej odsłonach historycznej i praktycznej), a także historią teatru i dramatu antycznego i współczesnego, szczególnie chętnie zaś ich dzisiejszymi filiacjami. Jest autorką książek poświęconych poznańskiemu teatrowi międzywojennemu i redaktorką wielu książek zbiorowych (ostatnio wraz z prof. Małgorzatą Leyko opracowała redakcyjnie tom Awangarda teatralna $w$ Europie Środkowo-Wschodniej), współpracuje także z takimi pismami teatrologicznymi, jak „Dialog” i „Didaskalia”. Od 2017 roku dyrektorka Instytutu Teatru i Sztuki Mediów.

Ryszard K. Przybylski - profesor doktor habilitowany, literaturoznawca, kulturoznawca, badacz kultury popularnej; zajmuje się również teorią i historią mediów oraz semiotyką komunikacji i teorią kultury, w tym kultury mediów cyfrowych. Autor książek o Gustawie Herlingu-Grudzińskim (Być i pisać) i Leopoldzie Tyrmandzie (O tym, jak Leopold Tyrmand watęsat sięw świecie kultury popularnej), a także zbioru tekstów Wszystko inne: szkice o literaturze, sztuce i kulturze wspótczesnej. W latach 2001-2011 był kierowni- 
kiem Pracowni Semiotyki Wizualnej w Katedrze Komunikacji Wizualnej asP (obecnie: Uniwersytet Artystyczny) w Poznaniu, od 2008 roku pełni funkcję kierownika Zakładu Literatury i Kultury Nowoczesnej Wydziału Filologii Polskiej i Klasycznej UAM w Poznaniu. 
